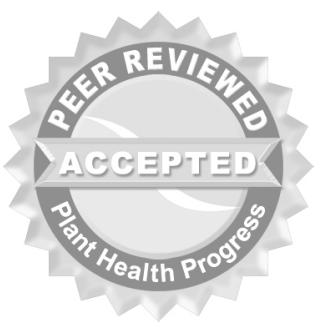

(c) 2007 Plant Management Network.

Accepted for publication 7 J une 2006. Published 19 February 2007.

\title{
First Report of Fusarium circinatum, Causal Agent of Pitch Canker Disease, from the Roots of Mature Aleppo Pines in California
}

M. Garbelotto and W. Schweigkofler, Department of ESPM-ES, 137 Mulford Hall, University of California, Berkeley 94720; and D. Shaw, and 5555 Overland Avenue, Suite 4101, University of California Cooperative Extension, San Diego 92123

Corresponding author: Matteo Garbelotto. matteo@nature.berkeley.edu

Garbelotto, M., Schweigkofler, W., and Shaw, D. 2007. First report of Fusarium circinatum, causal agent of pitch canker disease, from the roots of mature Aleppo pines in California. Online. Plant Health Progress doi: 10.1094/PHP-2007-0219-01-BR.

In 2001, an unusual rapid decline of ten 20-year-old Aleppo pines (Pinus halepensis) was observed in the parking lot of the Legoland amusement park $\left(33^{\circ} 7^{\prime} 34.2^{\prime \prime} \mathrm{N}, 117^{\circ} 18^{\prime} 41.4^{\prime \prime} \mathrm{W}\right)$ in San Diego Co., California. Crowns of affected trees were at varying stages of chlorosis, ranging from pale green to yellow (Fig. 1). Inspection of the aerial parts of symptomatic trees failed to detect any signs of a putative pathogen. Although no external symptoms were observed, upon removal of the bark in the primary woody roots, we identified diffuse black elongated lesions and abundant internal resinosis (Fig. 2). Lesions could be followed along the roots for at least $50 \mathrm{~cm}$ on average from the root collar and well into the underground portion of primary roots. Lesions were present around most of the circumference of the root collar of chlorotic trees, suggesting the above-ground symptoms were the result of girdling action by a pathogen. Trees displaying symptoms were in different parts of the large $\left(>200,000 \mathrm{~m}^{2}\right)$ parking lot.

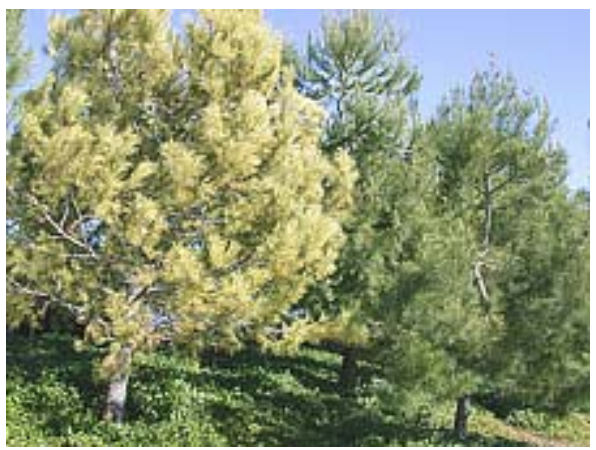

Fig. 1. The chlorotic crown of an Aleppo pine (left) whose roots are colonized by Fusarium circinatum.

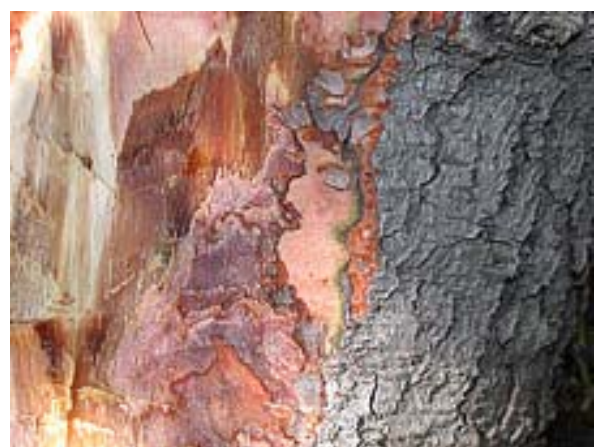

Fig. 2. Resin-soaked sapwood was observed under bark of primary-woody roots and root collars. Fusarium circinatum was always isolated from such lesions. 
Ten small chips of wood from the margin of lesions from each of four symptomatic trees were plated on the following media: Phytophthora-selective corn meal-based pimaricin-ampicillin-rifampicin-PCNB (PARP), Fusarium selective PCNB (penta chloro nitro benzene) media, antibiotic enriched 0.1× potato dextrose agar (PDA), and antibiotic enriched $0.1 \times$ malt extract agar (MEA). While no other pathogenic organism was isolated on any of the tested growth media, all isolations on Fusarium-selective PCNB media resulted in the growth of colonies of the same fungus. Conidia produced in vitro, PCR amplification using both Fusarium circinatum-specific primers (2) and primers specific for the identification of Fusarium mating alleles (3), identified all isolates as Fusarium circinatum belonging to MAT1, the only mating type ever detected in California. Sequencing of a portion of the IGS rDNA region (GENBANK accession DQ388478) confirmed the identity of the isolates. Despite removal of diseased trees upon their death, in 2004 we further confirmed the presence of $F$. circinatum on three additional trees displaying the generalized crown symptoms described above.

Although Aleppo pine is a known host for F. circinatum (2), this is the first report describing resin-soaked sapwood lesions in the roots of mature trees. Previous reports on root infections regarded exclusively seedlings (4). The infestation in this location may potentially have begun with infected roots in planted saplings. It is not known if additional spread from diseased to healthy trees may be occurring at this site, and the mode of such spread (e.g., vegetative, insect vector, or airborne) is not clear. The persistent infestation at Legoland represents a significant source of inoculum for this pathogen exotic to San Diego Co. and to California in general (1). In cases such as this, the timely recognition of new symptoms caused by an otherwise already known pathogen is of paramount importance in order to be able to recommend the opportune sanitation practices aimed at curtailing further spread of the disease.

\section{Literature Cited}

1. Gordon, T. R., Storer, A. J ., and Wood, D. L. 2001. The pitch canker epidemic in California. Plant Dis. 85:1128-1139

2. Schweigkofler, W., O'Donnell, K., and Garbelotto, M. 2004. Detection and quantification of airborne conidia of Fusarium circinatum, the causal agent of pine pitch canker, from two California sites by using a real-time PCR approach combined with a simple spore trapping method. Appl. Environ. Microbiol. 70:3512-3520.

3. Steenkamp, E. T., Wingfield, B. D., Coutinho, T. A., Zeller, K. A., Wingfield, M. J ., Marasas, W. F. O., and Leslie, J. F. 2000. PCR-based identification of MAT-1 and MAT-2 in the Gibberella fujikuroi species complex. Appl. Environ. Microbiol. 66:4378-4382.

4. Viljoen, A., Wingfield, M. J., and Marasas, W. F. O. 1994. First report of Fusarium subglutinans f. sp. pini on pine seedlings in South Africa. Plant Dis. 78:309-312. 